Acta Universitatis Wratislaviensis • No 4055

Literatura i Kultura Popularna XXVII, Wrocław 2021

https://doi.org/10.19195/0867-7441.27.20

\author{
Paulina Korzeniewska-Nowakowska \\ ORCID: 0000-0001-7878-7956 \\ Uniwersytet Zielonogórski
}

\title{
Literary Representation of Sport in Historical Turmoil: On Józef Hen's The Boxer and The Death
}

\author{
Keywords: sports writing, Józef Hen, Holocaust writing \\ Słowa kluczowe: literatura sportowa, Józef Hen, literatura holokaustu
}

\section{Introduction}

It is with little regard that Polish academics, critics, and readers have treated sports writing. Putting aside all possible reasons for such undervaluation of what has become a solid branch of literature in the western cultural expression, there simply is no tradition of sports writing in Poland. We do pride ourselves on a few instances of twentieth-century brilliant and internationally acclaimed sports pieces, such as Kazimierz Wierzynski's Olympic Laurel (1927), which reached wider audiences as it had won the gold medal for poetry at the 1928 Amsterdam Olympic Games, when art competitions were still held as part of the summer Olympic Games, or Tadeusz Borowski's This Way for the Gas, Ladies and Gentlemen (1947), a canonic short story which, although it may be surprising, is frequently taught in academic sports writing courses in the United States. However, sport is not usually a separate theme or leitmotif in Polish prose or poetry and, therefore, there are no writers whom we call sports writers. The American literary tradition shaped authors such as Jack London, Ernest Hemingway, Bernard Malamud, or David Foster Wallace, just to name a few, who have been recognized as those who deployed sport as an artistic tool to convey social, political, historical, and personal messages, whereas in Poland there are no such names. Following in 
the footsteps of Hollywood, Polish cinematography has timidly started using this subject as a leading topic of sports biopics, as Polish filmmakers most probably realized sport stories may offer multi-layered and engaging screen plays. (Łukasz Palkowski's Najlepszy [2017] is worth mentioning as a complex and acclaimed movie whose plot is thoroughly based on the sporting experience.) In the twentyfirst-century Polish literature, sport is practically nonexistent.

If there are no established Polish sports writers, then why not look for some? One of the authors who made his characters athletes and his settings - athletic arenas, is Józef Hen, novelist and screenwriter of Jewish origin. His short piece The Boxer and The Death tells a story of a Polish boxer who has been chosen as a sparring partner for a German commander in a concentration camp during the Second World War. The story is not only a study of the human mind and character, but it also offers a bitter analysis of a society tormented by political and historical unease. As such it also highlights sport, in this case boxing, as a crucial, socially engaged endeavour. This article aims at placing Hen's story in the Second World War experience of sport, analysing the text with a particular focus on its two main characters and pinpointing the elements which make it a classic sport narrative in a theoretical framework: its melodramatic inclinations and its main character being a representation of an Adonic hero, as problematized by Robert J. Higgs. Józef Hen has not been known internationally and domestically as a sports writer, so this can also be seen as an opportunity to introduce this episode of his work to a wider audience.

\section{"Every hero gets his moment of redemption" - Józef Hen's take on the Holocaust and sport}

Józef Hen (originally Józef Henryk Cukier) is a Warsaw-born novelist, essayist, reporter, and screenwriter, whose literary career has spanned over seven decades. Drawing heavily from the historical and social struggle of the war and postwar experience, Hen is mostly known for ugi authoring the screenplay to Jerzy Hoffman and Edward Skórzewski's cult The Law and the Fist (1964) and Kazimierz Kutz's Nobody's Calling (1960), young adult novels, multiple short story collections, autobiographical pieces, and memoirs. Hen's protagonists are often war victims and re-emigrants desperately struggling to escape their traumatic past and start anew in the post-conflict landscapes, ideologically divided and, not infrequently, devoid of moral values. Aleksander Jackiewicz notices the 'film quality' of Hen's writing, his non-traditional approach to novellas and the confessional style. ${ }^{2}$ On the other

${ }^{1}$ R. Didinger, G. Macnow, The Ultimate Book of Sports Movies, Philadelphia, PA 2009, p. 10.

2 A. Jackiewicz, "Introduction", [in:] J. Hen, Bokser i Śmierć. Wybór opowiadań, Warszawa 1975 , p. 1.

Literatura i Kultura Popularna XXVII, Wrocław 2021

(C) for this edition by CNS 
hand, he points out his unconstrained, not overly cerebral world perception and dedicated engagement with human rights.

The Boxer and The Death, first published in $1956,{ }^{3}$ is not the sole sporting piece in Hen's literary output; it should be read and contextualized along with, e.g., Deptula's Great Run (1956) and Slapping (1959) $)^{4}$ — two stories problematizing Polish longing for sporting success in spite of war decay, poverty and absolute negligence of sport institutions in the light of rough and hopeless reality of the Polish People's Republic of the 1950s. Hen reminisces about Deptula's Great Run in his memoir, saying that it is "a story of sporting mythomania [...] Deptula, in his final run, was doubled over many times, and yet there was something heroic in his struggle; a lonely long-distance runner, insulted and hit by bottles coming from a disappointed group of spectators, finished his race trotting. He did not surrender". ${ }^{5}$ In 1962, a Slovak director Peter Solan used The Boxer and Death as a basis for his sports drama, Boxer a Smrt.

As has already been mentioned, Polish sports writing has never gained much attention from critics or readers; those few pieces of twentieth-century sports writing which have seem to be immersed in the Second World War experience. At the same time, Holocaust writing holds a very strong position in the Polish literary tradition, constituting the literary canon and following the nation's inclination towards its martyrdom myth. A number of sociological and historical studies have reported on the importance of sport, especially boxing, in the Second World War concentration camps. Mateusz Pawlak, for instance, identifies two levels of camp sport in Auschwitz Birkenau - "normal", as he puts it, and pathological. The "normal" one reflected the traditional character of sport, meaning it was not perceived as a punishment or torment; it served as entertainment for the prisoners. They would play soccer, volleyball, practice fencing and boxing. Physical activity would even be rewarded with additional food rations. It was both spontaneous and initiated by the SS guards themselves. That form of sport was an integral part of the camp cultural life, offering short moments of relief and relaxation. However, Pawlak highlights the other, darker face of sport in the camp reality, "pathological", as he calls it. In that sense, sport was associated with torture, oppression, or even death. It was used as one from among the forms of punishment for the prisoners' alleged breaches of the camp rules; the guards would call it a drill or pseudo-sport. For example, the prisoners were forced to jump on one leg, do squats and burpees, crawl on their elbows, etc. Such practices obviously led to emaciation and were something the camp prisoners were afraid of. ${ }^{6}$

${ }^{3}$ See J. Sładek and M. Tomecka, Józef Hen. Bibliografia w wyborze, Katowice 2016, p. 15.

${ }^{4}$ Ibidem.

5 J. Hen, Nie boję się bezsennych nocy, vol. 1, Warszawa 2013, p. 177. (All translations from Polish - P.K.N.).

${ }^{6}$ M. Pawlak, "Rola sportu w życiu codziennym w niemieckim obozie koncentracyjnym Auschwitz-Birkenau oraz jego podobozach", Prace Naukowe Akademii im. Jana Dtugosza w Częstochowie 16, 2017, pp. 401-413.

Literatura i Kultura Popularna XXVII, Wrocław 2021

(C) for this edition by CNS 
Meanwhile, Paweł Wolski extensively analyzes boxing in Holocaust narratives, formulating a few cogent arguments. He notices a very corporeal aspect of the Holocaust experience in literature; a peculiar representation of sport as a phenomenon posited between the cultural and the natural. Placing body and mind as opposites, he argues, is artificial, as sporting narratives tend to place body in the center. ${ }^{7}$ It is in this somatic perspective that Wolski undertakes the analysis of Hen's The Boxer and The Death in his article Boks w Auschwitz. Opór ciała [Boxing in Auschwitz. Resistance of the Body]. ${ }^{8}$ Through reading Holocaust sporting writing, he also distinguishes a clear emanation of Nazi masculinity: immanent and contingent. ${ }^{9}$

Boxing played a significant role in the Auschwitz Birkenau camp, as boxing matches were held there on a regular basis. Outstanding boxers were better fed so that they could gain necessary strength and weight; the best ones would compete with German camp foremen. And that is the story of Tadeusz "Teddy" Pietrzykowski, who had been a successful, promising young boxer before the war and while being in the camp he was fighting, and winning, against a German champion, Walter Dunning. The Boxer and The Death is loosely based on the war camp experience of Pietrzykowski. ${ }^{10}$ Józef Hen managed to combine these two terrains of Holocaust and the sporting element in his short story. Hen's protagonist, Janusz Kominek, is compelled to be a sparring partner for the camp commander, Walter Kraft, in the fictional concentration camp in Bąków, near Kluczbork. Kraft dreams of a sporting career after the war and wants to preserve his stamina and technique. Kominek has no choice but to agree to participate in these fights and, obviously, lose them in order not to offend his opponent and provoke his anger. He befriends a former boxing coach, Węźlak, and becomes determined to survive the sparrings and rebuild his sporting excellence. The boxing matches between Kominek and Kraft become highly symbolic encounters in which human dignity and will for survival are at stake.

It is with precision that Hen shapes these two opposing characters, Kominek and Kraft, as these figures symbolically represent the conflict in the story. The author vividly confronts the two characters and the realms they represent. At first, Kominek (which is Polish for 'chimney' and brings to mind horrendous images of crematoria and desecration of the human body) comes off as weak, fearsome,

7 P. Wolski, "Albo bokser, albo bandyta: etyczny obraz walczącego ciała w literaturze obozowej", Porównania 2017, no. 2 (21), pp. 215-223.

${ }^{8}$ P. Wolski, "Boks w Auschwitz. Opór ciała", [in:] Adlojada. Biografia i świadectwo, eds. J. Brejdak et al., Szczecin 2014.

9 See P. Wolski, "Eksces męskości. Narracje bokserskie w literaturze Zagłady”, Teksty Drugie 2015, no. 2, pp. 180-202.

10 Marta Bogacka offers a detailed account of Pietrzykowski's life and career in her article "Obozowe lata Tadeusza Pietrzykowskiego - boksera, który pięściami wywalczył sobie życie”. She does not, however, draw any analytical parallels between the figure of Pietrzykowki and Hen's protagonist. 
fully dependant on his rival's will, struggling with his physical tiredness and confusion due to heavy malnutrition.

Kominek looked at his boxing gloves, surprised. He is going to fight in a moment! He squatted, jumped a few times, until his joints creaked. He felt weak, as if he had been ill for ages; weak as a child. And now he needs to fight. Whom? The champion of champions! If he is not good enough, he will end up in the oven. ${ }^{11}$

The experience he is having with Kraft seems unreal to him. The real life, he says, is going on in the gas chamber, not on the boxing ring. He, however, seems extremely persistent in his pursuit for endurance, which finds its reflection in his later actions. Hen closely examines his restorative psyche, as Kominek gains weight and becomes more self-confident and finally, enraged by Węźlak’s death, stands up to Kraft with determination and fury.

Kraft (German for 'strength, power') has been punished for muttering some bitter words about Hitler and sent to the camp, exiled even. Hen presents him as a failed intellectual, frustrated athlete; Kraft claims he is prisoner himself.

Kraft hated his prisoners because he felt like an exile, just like them. If it weren't for them, he thought, he wouldn't be stuck here; he would hold court in his hometown, Hamburg. But most and foremost — he would be able to fight. Thirty-seven-year-old, Kraft still had an outstanding right hook, a good boxing eye and was highly skilled in terms of technique. Boxing was not only a profession to him - it was his passion. He wasn't characterized by his intellect. As most German townsmen, he would read books, go to the opera and attend concerts, but he would do all that out of obligation. ${ }^{12}$

The story's opening is a narrative that offers Kraft's point of view. He is an embodiment of the Nazi strength — well-built, confident, arrogant; loyal to the regime. He once read Nietzsche and understood that a good boxer is an Übermensch; he read Schopenhauer and drew a conclusion that he is no subject to any restrictions or limits. Kraft claims he is filled with disgust for Jews but he does not wish to investigate that sentiment further. That very feeling also gives him the euphoria of supremacy. What is disturbing and causes almost instant antipathy towards the character is his resentment and sense of wrong. Surrounded by murders, atrocities, and utter dehumanization, it is Kraft who feels hurt, sidelined, inequitably sent to the camp as if it were a punishment. His almost postcolonial image of an oppressor who, in his own understanding, becomes a victim is a final straw to the character's development.

Owing to his pertinacious character, but also his sporting background, Kominek finally beats his opponent; in the climax of the story, just before the final fight, he is extremely embittered as Kraft sent Kominek's friend and coach to the gas chamber. The sporting value of sports excellence he wants to manifest translates into his attitude towards the realm he opposes. Kominek in this final

11 J. Hen, Bokser i Śmierć. Wybór opowiadań, Warszawa 1975, pp. 15-16.

12 Ibidem, p. 7. 
fight represents the attempt to promote values such as equality among people and respect for human rights. He bravely opposes Kraft in the climax; he takes the initiative and defeats a much stronger boxer. On the one hand, Kominek symbolically avenges the victims who cannot speak for themselves; on the other - he is personally involved and wants to show his sporting talent and skills.

Kominek undergoes a transformation and becomes a powerful and adamant individual. There are a number of factors contributing to overcoming the evil personified by Kraft. Gaining the courage of his own convictions, survival instinct, patriotic convictions, sporting self-will, and pursuit of excellence all accumulate in the final fight. Hen attempts to show Kominek not only as a hero, but also as an advocate for an equal and peaceful world. It also places Hen's story in a very classic, Western pattern of a sports narrative, both literary and cinematic. The story conforms to two theoretical assumptions concerning sports fiction: its melodramatic characteristics and Robert J. Higgs's archetypical models of an athlete as shaped in literature.

\section{Theorizing athletes in literature}

A basic theme for a sports narrative is "the triumph of the underdog, the scrappy athlete or team that prevails in spite of the odds". ${ }^{13}$ Written to appeal directly and strongly to the audience's emotions, it fulfils the criteria of the melodrama. Schematic melodramatic components defined by Steve Neal, which the author based on the nineteenth-century stage melodrama, yet applied to the twentieth-century literary, television and cinematic expressions, are as follows: the depiction of conflict between evil and good, eventual victory of the latter, principal characters of hero (and/or heroine) and villain, demonstrative aesthetics, episodic, formulaic, and action-packed plots, highly emotional situations, or vivid tableaux which form moments of dramatic turns. ${ }^{14}$ It could be argued that all these elements find their representation in The Boxer and The Death. The conflict between the story's protagonist (a hero) and his antagonist (a black-and-white villain) offers an archetypical struggle between the good, noble, and just and the evil, corrupted, and rotten, in which the good prevails. The way Hen develops the plot is simple: he abandons detailed, psychological profiling of his characters in favor of stereotypical characters whose qualities and intentions are vividly depicted via boxing encounters. As Didinger and Macnow notice, "boxing lends itself to melodrama. It is about an individual, not a team, so the writer can focus on one storyline". ${ }^{15}$ Interestingly,

${ }^{13}$ R. Didinger, G. Macnow, op. cit., p. 10.

${ }^{14} \mathrm{~S}$. Neale, "Melo talk: on the meaning and use of the term 'melodrama' in the American trade press", Velvet Light Trap 32, 1993, pp. 66-89, Gale Academic Onefile, https://bit.ly/3BjJtOs (accessed: 14.08.2019).

15 R. Didinger, G. Macnow, op. cit., p. 93. 
although melodramatic narratives are identified as those attracting a female audience, ${ }^{16}$ as Hen's story shows, the genre easily adapts to the boxing realm (rightly or not, associated with the circle of masculine interests).

The story's protagonist could also be seen as an admirable Adonic figure, as identified by Robert J. Higgs. In Laurel and Thorn: The Athlete in American Literature, ${ }^{17}$ Higgs divides athletes in literature into three categories. Appolonian types are know-it-all individuals, striving for a stereotyped concept of perfection; they are unrealistic and come across as rather immature. A Dionysian type is "the neurotic who wants to be himself. He is the true 'natural' who has accepted his body as himself and feels no need to conform to an Appolonian order of any sort". 18 Finally, an Adonic figure - "to one degree or another he is a rebel". ${ }^{19}$ According to Higgs, Adonic heroes "share certain qualities: innocence, an innate moral sense, and love of life and independence, the folk hero seems to have certain characteristics that set him apart. Following the general pattern of the earliest folk heroes, he seems to spring from the soil". 20 "He does not conform to temporal codes on the one hand nor hedonistically indulge his body on the other. Hence he lives in the world of tension, pain, struggle, and hope". ${ }^{21}$ Although Higgs focuses his analysis on American characters in sports literature, ${ }^{22}$ it would not be without merit to argue that Janusz Kominek serves as a representative example of this Adonic profile. Rising from the impersonal mass of careworn, abased prisoners, he comes as a folk hero who symbolically wins dignity and humanity for his people. Sport offers him a nerve-wracking and physically exhausting, yet prodigious opportunity for a victorious finale.

\section{Conclusions}

Sports writing brings an interesting input to the studies of history and society in Polish literature, as these brief remarks I made hopefully have showed. The sporting experience phenomenon as expressed in literature is present in the Polish context. The character of Janusz Kominek selected for interpretation displays his patriotic involvement and negotiates the attributes of his identity through a broadly understood sporting activity. The story shows how crucial sport can be in the

16 J. Mercer, M. Shingler, Melodrama: Genre, Style, Sensibility, New York City 2005, p. 29-30.

17 R.J. Higgs, Laurel and Thorn. The Athlete in American Literature, Lexington, KY 1981.

18 Ibidem, p. 10.

19 Ibidem, p. 119.

20 Ibidem, p. 119.

${ }^{21}$ Ibidem, p. 11.

22 Higgs chooses Pat Glendon from Jack London's The Abysmal Brute, Roy Hobbs of The Natural by Bernard Malamud and characters from Mark Harris's baseball stories, among others, as epitomes of Adonic figures, and subdivides them even further, offering categories such as "The Country Boy from the City", "The Cripple", "The Absurd Athlete", etc. 
analysis and interpretation of a literary text and how Hen's work remains an inspiring and complex reading. The story is, so to speak, a sports bildungsroman; it is told within a structure depicting psychological and moral growth of the protagonist. It manifests political engagement, sacrifice, and dedication to the cause. It is also a portrayal of an individual entangled in the historical turmoil on the verge of great victory and liberation, a witness to political and social change. The protagonist shapes his identity as an athlete, a citizen, and a human being by means of sport. The article also analyzed the story within the framework of a melodramatic narrative and presented Kominek as an example of Higgs's Adonic character, which highlighted the story's universality and placed it among noteworthy sports literary pieces worldwide.

\section{Bibliography}

\section{Primary sources}

Borowski T., Proszę państwa do gazu, Biblioteka Akustyczna Lektury, Warszawa 2018.

Hen J., Bokser i Śmierć. Wybór opowiadań, Czytelnik, Warszawa 1975.

Hen J., Nie boję się bezsennych nocy, vol. 1, W.A.B, Warszawa 2013.

Wierzyński K., Laur Olimpijski, Estrella, Warszawa 2018.

\section{Secondary sources}

Bogacka M., "Obozowe lata Tadeusza Pietrzykowskiego - boksera, który pięściami wywalczył sobie życie”, Pamięć i Sprawiedliwość 2, 2012, no. 20, pp. 139-166.

Didinger R., Macnow G., The Ultimate Book of Sports Movies: Featuring the 100 Greatest Sports Films of All Time, Running Press, Philadelphia 2009.

Higgs R.J., Laurel \& Thorn. The Athlete in American Literature, The University Press of Kentucky, Lexington, KY 1981.

Mercer J., Shingler M., Melodrama: Genre, Style, Sensibility, Wallflower Press, New York City 2005.

Neale S. "Melo talk: on the meaning and use of the term 'melodrama' in the American trade press", Velvet Light Trap 32, 1993, pp. 66-89, Gale Academic Onefile, https://bit.ly/3BjJtOs (accessed: 14.08.2019)

Pawlak M., "Rola sportu w życiu codziennym w niemieckim obozie koncentracyjnym Auschwitz-Birkenau oraz jego podobozach", Prace Naukowe Akademii im. Jana Dtugosza w Częstochowie, 2017, vol. 16, pp. 401-413.

Sładek J., Tomecka M., Józef Hen. Bibliografia w wyborze, Biblioteka Śląska, Katowice 2016.

Wolski P., "Boks w Auschwitz. Opór ciała", [in:] Adlojada. Biografia i świadectwo, eds. J. Brejdak et al., Muzeum Narodowe w Szczecinie, Szczecin 2014, pp. 67-74.

Wolski P., "Eksces męskości. Narracje bokserskie w literaturze Zagłady”, Teksty Drugie 2015, no. 2, pp. 180-202.

Wolski P., "Albo bokser, albo bandyta: etyczny obraz walczącego ciała w literaturze obozowej”, Porównania 2017, no. 2 (21), pp. 215-223. 


\title{
Filmography
}

Boxer a Smrt [The Boxer and Death], dir. Peter Solan, Czechoslovakia 1963.

Najlepszy [The Best], dir. Łukasz Palkowski, Poland 2017.

Nikt nie woła [Nobody's Calling], dir. Kazimierz Kutz, Poland 1960.

Prawo i pięść [The Law and the Fist], dir. Jerzy Hoffmann and Edward Skórzewski, Poland 1964.

\section{Literary Representation of Sport in Historical Turmoil: On Józef Hen's The Boxer and The Death}

\begin{abstract}
Summary
The present article strives to analyze a sporting war short story The Boxer and The Death by Józef Hen as an exemplary piece of sports writing immersed in a historical context. Although there is no entrenched tradition of sports writing in the Polish literary expression, the story offers a very classic sports narrative anchored in the Holocaust reality. Following the presentation of the figure of Hen and providing historical background for sport in concentration camps, the author analyzes the story, focusing on its two main characters: Janusz Kominek and Walter Kraft, as well as the values and symbols they represent. It is also argued that The Boxer and The Death fulfills the criteria of a traditional western, melodramatic narrative, and conforms to Robert J. Higgs's Adonic model of an athlete in literature.
\end{abstract}


Literatura i Kultura Popularna XXVII, Wrocław 2021

(C) for this edition by CNS 